\title{
Exploratory Analysis of Factors Influencing Engineers to Teach at the Philippine State Universities in Ilocos Region
}

\author{
Paulo V. Cenas ${ }^{1}$, Frederick F. Patacsil, ${ }^{1, *}$, Marilou M. Fernandez ${ }^{2}$ \\ ${ }^{1}$ Department of IT, College of Computing, Pangasinan State University, Urdaneta City Campus, Philippines \\ ${ }^{2}$ Department of Mechanical Engineering, College of Engineering and Architecture, Pangasinan State University, Urdaneta City \\ Campus, Philippines
}

Received November 10, 2019; Revised January 8, 2020; Accepted February 3, 2020

Copyright $\bigcirc 2020$ by authors, all rights reserved. Authors agree that this article remains permanently open access under the terms of the Creative Commons Attribution License 4.0 International License

\begin{abstract}
This study is focus in determining the factors that influence the engineers to teach in state colleges and universities of Region I. The study is an exploratory analysis of the factors influencing engineers in Ilocos Region (Region I) to teach in state universities. The engineers were first described relating to their profile and work-related problems. After which, factor-analysis was performed to extract the underlying multiple and independent components out of eighteen (18) hypothesized influential variables to come up with a less explicit discussion in reduced dimension. A survey questionnaire developed by the researcher was used as the main data gathering instrument. Copies of the questionnaire were distributed to sixty-one (61) engineers teaching in the four major state universities in the provinces of Pangasinan, La Union, Ilocos Sur, and Ilocos Norte. They were selected using simple random sampling where results of descriptive statistical analysis revealed that they were of varying ages, mostly males, married and very few have earned a doctorate. Prior to teaching, most of the engineers have short industrial experience. A bulk of the faculty was new and old wherein the new faculty were occupying instructor positions on temporary or contractual status. The problems mostly encountered by them in their previous and present employment were moderately serious. The application of factor analysis resulted in the extraction of four components explaining $65 \%$ of the total variance. Such proportion explained the reasons why engineers opt to teach in a college where $35 \%$ of the total variance were shared by intrinsic factors.
\end{abstract} Keywords Intrinsic Factors, Opportunity,
Compensation, Engineers

\section{Introduction}

Engineers are the most in-demand and internationally sought-after profession. Engineers do various work from designing programs at a computer terminal to overseeing maintenance operations for major structures like aircraft, ships, heavy earth moving equipment, mobile cranes, offshore oil platforms, and many more. Job opportunities for engineers are lucrative and complex. As such, there are numerous large number of higher learning institutions offering various engineering degree programs[1].

Engineering has diverse fields i.e. aerospace, agricultural, automotive, biomedical, chemical, civil, sanitary, computer, electrical, geological, marine, and mechanical, petroleum, and software to name a few. Electrical, mechanical, civil, and agricultural engineering are mostly offered and in demand program courses in the Ilocos Region.

Instructors and professors with engineering degree programs and industry experience are considered assets in higher learning institutions. Their industry knowledge plays a major role in producing quality graduates conversant with engineering ethics, and link between technology and society. Compared to graduate of teacher education courses, opportunities for engineering instructors and professors are far wider outside the academe. Ideally, engineering schools should focus more on "real-world" engineering design and operations, including quality management; cover more material in frontier areas of engineering; offer more and better instruction in both oral and written communication skills and teamwork skills; provide training in critical and creative thinking skills and problem-solving methods [2].

Undeniably, opportunities for engineering graduates are far wider outside the academe. In some published tracer 
studies for graduates of engineering degrees in the past ten years, the employability indicated high, 95.54\% -Lyceum of the Philippines [3], 68\% -La Salle University[4], and 99\% -CSPC[5]. In the 2017 annual report by overseas job portal Workabroad.ph [6] the highest paying and most in-demand specializations other than healthcare and IT professionals are engineers. Land-based engineers are highly compensated in the Asia-Pacific while sea-based engineers receive the highest compensation in the USA.

Shortage of engineers is true in almost every sphere of engineering, and the greatest need is not in the design offices, test laboratories nor on the production floors, but in the corridors and classrooms of an academe [7]. The demand of engineers to teach in college has long been an issue to higher learning institutions for engineering studies. Engineers in the Philippines opt to teach in state universities with starting salary grade of SG-12. A salary grade of SG-12, based on the last four tranches of the salary standardization law [8], has an equivalent compensation of PHP 22, 938. Such compensation is not attractive compared to the compensation being offered for the engineers by the local or international industries. With this, the career of licensed engineers in the academe and the academe's institutional outcomes are at stake. However, according to Campbell "Many people say they're going into teaching because they want to make a difference and that their career in engineering wasn't as satisfying as they expected[13]." In addition, engineering and teaching seem like totally different profession, however science and maths knowledge that was polished throughout years in the industry is easily transferred to a school setting. In short, engineering course subjects should be taught by the licensed and experienced engineers for the application and development of new technology [7]. However, Limited researches related to the factors why engineers opt to work in the college or university exist. For an increasing number of engineers - hard hat-wearing civil engineers, chemical experts and everyone in between - that second career is teaching[13]. In addition, this research aids to understand the existing scarcity of the engineering instructors and professors in the Region 1; and recommend guidelines to ensure the engineering higher learning institutions to have sufficient faculty pool.

Hence, this study was made to analyze the factors influencing the engineers to pursue teaching profession in the Ilocos Region

\subsection{Objectives}

This study aimed to determine the factors that influence the engineers to teach in state colleges and universities of Region I.
Specifically, it sought the following objectives:

1. to characterize the engineers in terms of their personal and employment profiles;

2. to determine the work-related problems encountered by the engineers in their previous employment and present job as teachers;

3. to determine factors that encourage young engineers to teach in state universities; and

4. to measure the level of influence of the factors as multiple and independent components

\section{Methods}

This study utilized descriptive research technique. It described the characteristics of the population represented by the faculty engineers as respondents. The respondents were randomly selected from major state universities in the Ilocos region offering undergraduate engineering degree programs.

The questionnaire as research instrument is composed of three parts. Part 1 used to describe the profile of the respondents as to their age, sex, years in service and highest education. Part II used to determine the encountered problems of the engineers in their previous and current employment. Lastly, Part III identified variables that could explain why engineers teach in state universities and colleges.

Factor analysis was utilized in reducing the number of variables that describe the reasons why engineers choose to teach in state colleges or universities. This analysis explored the underlying theoretical structures of the phenomena in reduced dimension [9]. Although the number of samples used in the study was small $(<100)$, the use of factor analysis despite this size is warranted by the discussion of Shao [10], wherein conclusion, he stated that the general rule of thumb of the minimum sample size is not valid and useful and one can proceed with FA as long as his recommended rules concerning the overall $\mathrm{KMO}$, smallest communalities, eigenvalues, and cut-off values of loading size were carefully observed.

\section{Results and Discussion}

\subsection{Profile of the Engineers Teaching in State Universities}

Table 1 shows the personal profile of the respondents. Age was nearly uniformly distributed over the different categories. As expected more males than females. The majority of the respondents were married. Few earned doctoral degree. 
Table 1. Personal profile of the respondents teaching in state universities in the region $(\mathrm{n}=61)$

\begin{tabular}{|c|c|c|c|}
\hline Variable & Category & Frequency & Percent \\
\hline \multirow{4}{*}{ Age (in years) } & $<30$ & 14 & 22.95 \\
\cline { 2 - 4 } & 30 to 39 & 17 & 27.87 \\
\cline { 2 - 4 } & 40 to 49 & 13 & 21.31 \\
\cline { 2 - 4 } & $50>$ & 17 & 27.87 \\
\hline \multirow{3}{*}{ Sex } & Male & 40 & 65.57 \\
\cline { 2 - 4 } & Female & 21 & 34.43 \\
\hline \multirow{3}{*}{ Civil Status } & Single & 19 & 31.15 \\
\cline { 2 - 4 } & Married & 42 & 68.85 \\
\hline \multirow{3}{*}{ Education } & BS & 19 & 31.15 \\
\cline { 2 - 4 } & Earned MS units & 14 & 22.95 \\
\cline { 2 - 4 } & MS & 17 & 27.87 \\
\cline { 2 - 4 } & Earned PhD units & 5 & 8.20 \\
\cline { 2 - 4 } & Ph.D. & 6 & 9.84 \\
\hline
\end{tabular}

Table 2. Employment's profile of the respondents engineer teachers in state universities and colleges in the region

\begin{tabular}{|c|c|c|c|}
\hline Variable & Category & Frequency & Percent \\
\hline \multirow{3}{*}{$\begin{array}{c}\text { Previous } \\
\text { employment }\end{array}$} & none & 21 & 34.43 \\
\hline & industry/non-academics & 26 & 42.62 \\
\hline & teaching & 14 & 22.95 \\
\hline \multirow{3}{*}{$\begin{array}{l}\text { Years in the } \\
\text { previous } \\
\text { employment }\end{array}$} & $<5$ years & 44 & 72.13 \\
\hline & 5 to 10 years & 11 & 18.03 \\
\hline & 10 years $>$ & 6 & 9.84 \\
\hline \multirow{4}{*}{$\begin{array}{l}\text { Academic } \\
\text { rank in the } \\
\text { current } \\
\text { employment }\end{array}$} & Instructor & 31 & 50.82 \\
\hline & Assistant professor & 18 & 29.51 \\
\hline & Associate professor & 10 & 16.39 \\
\hline & Professor & 2 & 3.28 \\
\hline \multirow{3}{*}{$\begin{array}{l}\text { Years in the } \\
\text { present } \\
\text { employment }\end{array}$} & $<5$ & 24 & 39.34 \\
\hline & 5 to 10 & 10 & 16.39 \\
\hline & $10>$ & 27 & 44.26 \\
\hline \multirow{3}{*}{$\begin{array}{c}\text { Status of } \\
\text { employment }\end{array}$} & contractual & 25 & 40.98 \\
\hline & temporary & 16 & 26.23 \\
\hline & permanent & 20 & 32.79 \\
\hline
\end{tabular}

Table 2 shows the employment profile of the respondents in the region. Experience like actual exposure to facilities and equipment in the industry is important for an engineer. Experience is one of the most important qualification to become a good engineering teacher. Professor Magruder, mentioned that in order for a teacher has something to impart, he/she should have an appropriate education, training, experience, travel and observation, qualifications for a good teacher. In addition, an engineer should have rubbed elbows with workingmen of the artisan type and have measured himself/herself by the standards of knowledge and skill [12]. Ironically, many of the engineer teachers didn't have previous experiences in the industry prior to their entry in the college. They taught in other colleges or universities or first job was teaching in the state university. Majority of the engineer teacher have less than five years before teaching in a state university. In terms of Engineer teachers academic ranks are mostly instructors, very few of them are full-pledged professors. The data shows, a concave distribution of teacher engineers based on their experience in teaching in state university as a permanent, temporary or contractual status.

\subsection{Problems in Previous and Present Employment}

Table 3 shows the reasons why engineers shifted and left their previous workplaces. Some possible problems were identified and rated as to their degree of seriousness. As seen in Table 3, "stressful work" revealed the highest mean of 2.43 with low stress description. Other problems such as low salary, slow career advancement, uncomfortable workplace were all described as less serious. The respondents who considered the abovementioned problems as moderately serious to very serious should not be discounted nor neglected.

Problems encountered by engineers while in teaching were identified to shed light on leaving their teaching post issues. As shown in Table 4, this study identified overloading, slow promotion, rare opportunities, poor management, and low salary as problems. However, all these problems were generally considered less serious. This determines their mobility which is hardly predictable. In one study in the UK regarding teacher retention, solutions to teacher retention is challenging. Former teachers hardly provide practical suggestions in resolving retention issues they themselves faced with multilayered reasons [11].

Table 3. Problems in previous employment

\begin{tabular}{|c|c|c|c|c|c|c|c|}
\hline Problem & NS & LS & MS & S & VS & Mean & Desc \\
\hline Stressful work & 27 & 3 & 14 & 12 & 5 & 2.43 & LS \\
\hline Low salary & 28 & 4 & 13 & 13 & 3 & 2.33 & LS \\
\hline $\begin{array}{c}\text { Slow career } \\
\text { advancement/promotion. }\end{array}$ & 27 & 10 & 12 & 8 & 4 & 2.21 & LS \\
\hline Uncomfortable workplace & 28 & 9 & 14 & 10 & 0 & 2.10 & LS \\
\hline Poor management & 35 & 9 & 8 & 9 & 0 & 1.85 & LS \\
\hline $\begin{array}{c}\text { Lack of moral or motivational } \\
\text { support from the supervisor. }\end{array}$ & 34 & 11 & 10 & 6 & 0 & 1.8 & LS \\
\hline $\begin{array}{c}\text { Conflicts with } \\
\text { superiors/officemates }\end{array}$ & 40 & 8 & 8 & 5 & 0 & 1.64 & LS \\
\hline
\end{tabular}

*LS- less serious 
Table 4. Problems in present employment

\begin{tabular}{|c|c|c|c|c|c|c|c|}
\hline & NS & LS & MS & S & VS & Mean & Desc \\
\hline Work Overloading & 44 & 1 & 7 & 6 & 3 & 1.74 & LS \\
\hline Slow promotion & 45 & 1 & 8 & 4 & 3 & 1.67 & LS \\
\hline $\begin{array}{c}\text { Few opportunities } \\
\text { compared to industry }\end{array}$ & 44 & 2 & 9 & 3 & 3 & 1.67 & LS \\
\hline Poor management & 45 & 2 & 8 & 3 & 3 & 1.64 & LS \\
\hline $\begin{array}{c}\text { Slow professional } \\
\text { advancement }\end{array}$ & 46 & 1 & 9 & 3 & 2 & 1.59 & LS \\
\hline $\begin{array}{c}\text { Low salary } \\
\begin{array}{c}\text { Lack of hands-on } \\
\text { application and more of } \\
\text { theories }\end{array}\end{array}$ & 45 & 2 & 9 & 5 & 0 & 1.57 & LS \\
\hline
\end{tabular}

\subsection{Extracted Latent Structures}

Reasons why engineers choose to teach in a state university were sought. Factor analysis was conducted if the reason can be understood as a single factor or as comprising of multiple and independent components. To determine if factorability is possible, some measures of sampling adequacy were used such as the Kaiser-Meyer-Olkins and Bartlett's sphericity test. As Table 5 shows, the KMO coefficient exceeds 0.50 and Bartlett's test is significant. This is a good indication that factor analysis is possible.

Table 5. Results of the Sampling adequacy and sphericity tests

\begin{tabular}{|c|c|c|}
\hline Kaiser-Meyer-Olkin test & & 0.74 \\
\hline \multirow{2}{*}{ Bartlett's Test of Sphericity } & Approx. Chi-Square & 612.87 \\
\cline { 2 - 3 } & Sig. & 0.00 \\
\hline
\end{tabular}

Results of factor analysis revealed that 4 multiple independent components are extractable thus the success to reduce the dimensionality of the components from eighteen (18) to only four (4). By applying varimax rotation, the variances of the components have been maximized allowing eight variables to load on the first dimension, five variables to load on the second dimension, three variables on the third dimension and one to load on the last dimension. One variable did not successfully load on any of the four dimensions, and thus a candidate for exclusion.

Each of the four components explains a corresponding amount on the total variance. The component explaining the highest variance at close to $35 \%$ is the first component where the eight variables significantly loaded. With the addition of three more components, the total variance is a value above $65 \%$. This means that the four components explains $65 \%$ of the variation as seen in Table 6.

Table 6. Rotated Component Matrix

\begin{tabular}{|l|c|c|c|c|}
\hline & \multicolumn{4}{|c|}{ Component } \\
\cline { 2 - 5 } & 1 & 2 & 3 & 4 \\
\hline Sufficiency of the salary & -.08 & .13 & .78 & -.11 \\
\hline Workload is just enough to handle. & .09 & .10 & .71 & .20 \\
\hline $\begin{array}{l}\text { Persuasion of family to teach in } \\
\text { college }\end{array}$ & .05 & .80 & .19 & .03 \\
\hline Distance of the school from home & .03 & .57 & .18 & -.13 \\
\hline $\begin{array}{l}\text { A friend convinced me to enter } \\
\text { teaching. }\end{array}$ & -.14 & .58 & .04 & .34 \\
\hline $\begin{array}{l}\text { My family has a connection to where } \\
\text { I work. }\end{array}$ & -.19 & .65 & -.43 & .15 \\
\hline $\begin{array}{l}\text { Teaching is the first opportunity that } \\
\text { was offered to me. }\end{array}$ & .06 & .16 & .05 & .88 \\
\hline $\begin{array}{l}\text { I have a good working relation with } \\
\text { my colleague }\end{array}$ & .40 & -.09 & .42 & 0,48 \\
\hline Supportive administration & .31 & .24 & .63 & .09 \\
\hline $\begin{array}{l}\text { Teaching job suits to my health } \\
\text { concern. }\end{array}$ & .29 & .64 & .14 & .07 \\
\hline $\begin{array}{l}\text { It is my eager interest to teach } \\
\text { students. }\end{array}$ & .81 & .02 & .07 & .00 \\
\hline Teaching profession is my passion. & .84 & .15 & -.08 & .18 \\
\hline I find satisfaction in my work. & .91 & .01 & -.07 & .17 \\
\hline $\begin{array}{l}\text { I want to be part of the students' } \\
\text { academic progress/achievement. }\end{array}$ & .89 & -.10 & .22 & .00 \\
\hline I have a good rapport with students & .87 & .09 & .16 & .02 \\
\hline $\begin{array}{l}\text { I can exercise autonomy in delivering } \\
\text { instruction. }\end{array}$ & .82 & .09 & .16 & -.04 \\
\hline I find teaching a calling not a job. & .81 & -.02 & -.02 & .17 \\
\hline $\begin{array}{l}\text { I feel fulfilled whenever appreciated } \\
\text { by students }\end{array}$ & .76 & -.06 & .19 & -.15 \\
\hline
\end{tabular}


Table 7. Results of grouping into the different dimensions

\begin{tabular}{|c|c|c|c|c|}
\hline Component & Loaded items & Eigenvalue & Variance & \%variance \\
\hline \multirow{8}{*}{ I } & It is my eager interest to teach students. & \multirow{8}{*}{6.40} & \multirow{8}{*}{35.55} & \multirow{8}{*}{35.55} \\
\hline & Teaching profession is my passion. & & & \\
\hline & I find satisfaction in my work. & & & \\
\hline & $\begin{array}{l}\text { I want to be part of the students' academic } \\
\text { progress/achievement. }\end{array}$ & & & \\
\hline & I have a good rapport with the students & & & \\
\hline & I can exercise autonomy in delivering instruction. & & & \\
\hline & I find teaching a calling not a job. & & & \\
\hline & $\begin{array}{l}\text { I feel fulfilled when students appreciate the way I teach } \\
\text { them. }\end{array}$ & & & \\
\hline \multirow{5}{*}{ II } & Encouragement of family & \multirow{5}{*}{2.55} & \multirow{5}{*}{14.15} & \multirow{5}{*}{49.70} \\
\hline & Encouragement of friends & & & \\
\hline & Presence of relatives connected in the school & & & \\
\hline & Distance of the school from home & & & \\
\hline & Teaching job suited to health concern. & & & \\
\hline \multirow{3}{*}{ III } & Sufficiency of the salary & \multirow{3}{*}{1.72} & \multirow{3}{*}{9.56} & \multirow{3}{*}{59.26} \\
\hline & Favorable workload & & & \\
\hline & Good support of the administration to their faculty & & & \\
\hline IV & Teaching is the first opportunity that was offered to me. & 1.13 & 6.29 & 65.55 \\
\hline
\end{tabular}

By careful breakdown, each extracted component was given a name with consideration of the underlying factors thateach item represents. The most important component that highly influences engineers to teach in the university is considered intrinsic factors such as passion, satisfaction, fulfillment and individuality. The influence of other factors such as peer influences and physical comfort, compensation, workload and administrative support, and instant opportunity are moderate.

\subsection{Level of Influence of the Factor-Analyzed Component}

Table 8. Factor-Analyzed Results

\begin{tabular}{|c|c|}
\hline Factors & Mean \\
\hline \multicolumn{2}{|l|}{ Intrinsic factors (Fulfillment and individuality) } \\
\hline It is my eager interest to teach students. & 4.11 \\
\hline Teaching profession is my passion. & 3.85 \\
\hline I find satisfaction in my work. & 4.00 \\
\hline I want to be part of the students' academic progress/achievement. & 4.15 \\
\hline I have a good rapport with the students & 4.05 \\
\hline I can exercise autonomy in delivering instruction. & 3.85 \\
\hline I find teaching a calling not a job. & 3.89 \\
\hline I feel fulfilled when students appreciate the way I teach them. & 4.15 \\
\hline Mean & $\begin{array}{c}4.01 \\
(\mathrm{High})\end{array}$ \\
\hline \multicolumn{2}{|l|}{ Peer influences and physical comfort } \\
\hline Encouragement of family & 2.62 \\
\hline Encouragement of friends & 2.21 \\
\hline Presence of relatives connected in the school & 1.77 \\
\hline Distance of the school from home & 3.26 \\
\hline Teaching job suited to health concern. & 3.26 \\
\hline Mean & 2.62 (moderate) \\
\hline \multicolumn{2}{|l|}{ Compensation, workload and administrative support } \\
\hline Sufficiency of the salary & 3.21 \\
\hline Favorable workload & 3.38 \\
\hline Good support of administration to their faculty & 3.66 \\
\hline Mean & 3.42 (moderate) \\
\hline \multicolumn{2}{|l|}{ Instant Opportunity } \\
\hline Teaching is the first opportunity that was offered to me. & 2.38 \\
\hline Overall Mean & 3.14 (moderate) \\
\hline
\end{tabular}




\section{Conclusions and Recommendations}

On the basis of the findings of this study, it is concluded that engineers teach in state universities are predominantly males, young, and have a minimum industry experience of less than 5 years. The results revealed that stressful work is one reason they shift into teaching. Furthermore, most engineers teach in state universities out of their passion for teaching. The feelings of fulfillment, satisfaction and freedom they can experience in teaching, motivate them to enter the academic profession are considered intrinsic factors which should be given utmost importance. It's by these that school administrator should find ways to provide opportunities to enrich learning particularly of those in the engineering programs. Engineers can become successful as a teacher if they produce successful students. This can be achieved if the teachers deliver instruction in an excellent learning environment for the students. The autonomy or academic freedom of the teachers to exercise their teaching ability should be considered. As engineers were not trained as teachers, school administrators should conduct seminars and professional development programs for engineers or other teachers of technical programs to be trained in terms of teaching pedagogy. Although no single reason can be isolated to answer issue on faculty mobility, school administration should still look into other key considerations for better communication in answering less serious problems our engineers experience on workload reduction, promotion or recognition, and salary compensation. It is also recommended that the administrations will push the engineers to pursue their masteral and doctoral degree to develop their understanding in teaching techniques. For future researchers, it is recommended to add additional parameters on how to motivate engineers to teach in college and factors that will encourage them to stay in the academe.

1. to characterize the engineers in terms of their personal and employment profiles;

2. to determine the work-related problems encountered by the engineers in their previous employment and present job as teachers;

3. to determine factors that encourage young engineers to teach in state universities; and

4. to measure the level of influence of the factors as multiple and independent components

\section{REFERENCES}

[1] Engineers Australia, "What is Engineering" retrieved from https://www.engineersaustralia.org.au/For-Students-And-E ducators/Engineering-Careers/What-Is-Engineering

[2] Rugarcia, R.M. Felder, J.E. Stice, and D.R. Woods, "The Future of Engineering Education: I. Teaching Methods that
Work." Chem. Engr. Education

[3] Dotong, Condrado et.al., Tracer study of engineering graduates of one higher education institution in the Philippines for AY 2009-2012. European journal of engineering and technology

[4] A Tracer Study of La Salle University College of Engineering

Graduates retrieved from https://www.lsu.edu.ph/applicati on/files/1114/7193/8568/Vol._18_No._1_-_A_Tracer_Stu dy_of_La_Salle_UniversityCollege_of_Engineering_Grad uates.pdf

[5] Pontillas, Virginia V, Tracer Study on Bachelor of Science in Electrical Engineering Graduates of a Polytechnic College in the Philippines from 2007 to 2010, Asia Pacific Journal of Multidisciplinary Research, Vol. 6, No. 2, May 2018.

[6] https://www.workabroad.ph/article/156/WorkAbroad-ph--S ea-based-engineers--healthcare-professionals-are-highly-pa id-overseas

[7] Excel, John Academia's engineering skills shortage retrieved

from https://www.theengineer.co.uk/issues/december-2013 -online/academias-engineering-skills-shortage/

[8] Executive Order no. 201,s. 2016 retrieved from https://ww w.officialgazette.gov.ph/2016/02/19/executive-order-no-20 1-s-2016/

[9] Exploratory Factor Analysis retrieved from https://www.sta tisticssolutions.com/factor-analysis-sem-exploratory-factor -analysis/

[10] Shao, Nathan, The Minimum Sample Size in Factor Analysis retrieved from https://www.encorewiki.org/display/ nzhao /The+Minimum+Sample+Size+in+Factor+Analysis

[11] CooperGibson Research. Factors affecting teacher retention: qualitative investigation: Research report, March 2018. ISBN:

978-1-78105-855-8 retrieved from www.gov.uk/governme nt/publications

[12] WM. T. Magruder, The good engineering teacher: his personality and training. Science. August 1, 1913 retrieved from https://www.jstor.org/stable/1639606?seq=1\#metadat a_info_tab_contents

[13] https://this.deakin.edu.au/career/the-benefits-of-a-career-ch ange-for-engineers-to-teaching

[14] Bilbao, Purita et.al (2006). "The Teaching Profession". Philippines. Lorimar Publishing Co., Inc. 